CONSTRUCTING AUTOCRACY 



\title{
CONSTRUCTING AUTOCRACY
}

\author{
ARISTOCRATS AND EMPERORS
}

IN JULIO-CLAUDIAN ROME

MATTHEW B. ROLLER

PRINCETON U N I E R I T Y PRES S

PRINCETON A N OXFOR D 
Copyright $($ C 2001 by Princeton University Press

Published by Princeton University Press, 41 William Street,

Princeton, New Jersey 08540

In the United Kingdom: Princeton University Press, 3 Market Place,

Woodstock, Oxfordshire OX20 1SY

All Rights Reserved

Library of Congress Cataloging-in-Publication Data

Roller, Matthew B., 1966-

Constructing autocracy : aristocrats and emperors in Julio-Claudian Rome /

Matthew B. Roller.

p. $\mathrm{cm}$.

Includes bibliographical references and index.

ISBN 0-691-05021-X (alk. paper)

1. Rome - History - The five Julii, 30 B.C.-68 A.D. 2. Aristocracy (Political science)-

Rome. 3. Emperors-Rome. 4. Class consciousness-Rome. I. Title.

DG281 .R65 2001

937'.07-dc21 00-056511

This book has been composed in Sabon.

The paper used in this publication meets the minimum requirements of ANSI/NISO Z39.48-1992 (R1997) (Permanence of Paper)

www.pup.princeton.edu

Printed in the United States of America

$\begin{array}{llllllllll}10 & 9 & 8 & 7 & 6 & 5 & 4 & 3 & 2 & 1\end{array}$ 
For my sisters Emily and Elinor, and for Rhonda 
